\title{
Article
}

\section{The menopause and hormone replacement therapy}

\author{
Nuttall, Dilyse \\ Available at http://clok.uclan.ac.uk/21257/ \\ Nuttall, Dilyse ORCID: 0000-0002-0561-5229 (2014) The menopause and \\ hormone replacement therapy. Nurse Prescribing, 13 (1). pp. 14-16. ISSN \\ 2052-2924
}

It is advisable to refer to the publisher's version if you intend to cite from the work.

For more information about UCLan's research in this area go to

http://www.uclan.ac.uk/researchgroups/ and search for < name of research Group>.

For information about Research generally at UCLan please go to http://www.uclan.ac.uk/research/

All outputs in CLoK are protected by Intellectual Property Rights law, including Copyright law. Copyright, IPR and Moral Rights for the works on this site are retained by the individual authors and/or other copyright owners. Terms and conditions for use of this material are defined in the policies page.

\section{CLoK}

Central Lancashire online Knowledge www.clok.uclan.ac.uk

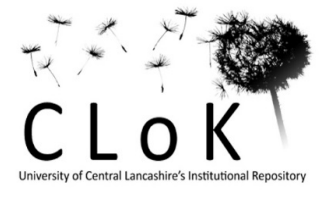




\section{Calculation Skills: Menopause \& Hormone Replacement Therapy}

National Institute of Health and Care Excellence [NICE] are currently developing guidelines on the diagnosis and management of menopause and these are due for release in October 2015. This is a welcome development which acknowledges the significant impact that the symptoms related to the menopause can have on the individual. NICE (2013) identify menopause as the ending of menstruation resulting from a failure in ovarian follicular activity. The changes in hormone levels commonly cause uncomfortable symptoms which include hot flushes; night sweats; dyspareunia; vaginal dryness and discomfort and disturbed sleep (NICE, 2013). The average woman's age at menopause is 52 years. According to NICE (2013), $80 \%$ of women will endure the symptoms of menopause and $45 \%$ of those would consider the symptoms to be distressing.

\section{Question 1}

Mary works in a large organisation where $65 \%$ of the 400 staff are female. Based on the NICE (2013) estimates, identify how many women (rounded up or down to nearest whole number) in Mary's organisation are likely to experience distressing menopausal symptoms.

Question 2

Although some women are able to manage the symptoms with lifestyle changes, it is recognised that some women benefit from the use of hormone replacement therapy to manage their distressing symptoms. However, HRT is not without risk and so the benefits should be considered alongside the risks to the individual woman (JFC, 2014). Risk can be reduced by prescribing the minimum effective dose for the shortest period (JFC, 2014). Table 1 highlights some of the risks associated with HRT use (JFC, 2014).

\begin{tabular}{|l|l|l|l|l|}
\hline \multicolumn{2}{|l|}{ Table 1 Source JFC (2014) } & $\begin{array}{l}\text { Incidence per } \\
\text { 1000 women not } \\
\text { using HRT } \\
\text { (over 5 yrs) }\end{array}$ & $\begin{array}{l}\text { Additional } \\
\text { cases per 1000 } \\
\text { women using } \\
\text { Oestrogen only } \\
\text { HRT } \\
\text { (for 5 yrs use) }\end{array}$ & $\begin{array}{l}\text { Additional } \\
\text { cases per 1000 } \\
\text { women using } \\
\text { combined HRT } \\
\text { (for 5yrs use) }\end{array}$ \\
\hline Breast Cancer & Age range & 2 & 6 \\
\hline Venous & $50-59$ & 10 & 3 & 9 \\
thromboembolism & $60-69$ & 15 & 2 & 7 \\
\hline Stroke & $60-59$ & 5 & 2 & 10 \\
\hline & $50-59$ & 8 & 1 & 1 \\
\hline
\end{tabular}

(i) How many women $60-69$, out of a population of 5000 , who are not using HRT, would experience breast cancer?

(ii) In a population of 20,000 women using oestrogen only HRT, spanning the age range of 50-69, how many additional cases of venous thromboembolism would be expected?

(iii) How much higher (expressed as a fraction) is the incidence of stroke in 60-69 year old women using combined HRT for 5 years?

(iv) Expressed as a percentage, how many more cases of breast cancer are there with combined HRT use, than non-HRT use (in the 50-59 years age group)? 


\section{Question 3}

Mary is prescribed low dose conjugated oestrogens with progestogen for her menopausal symptoms. Each tablet contains 300 micrograms of oestrogen and $1.5 \mathrm{mg}$ of medroxyprogesterone. She is to take 1 tablet per day. The tablets are available as 28 -tablet packs, at a cost of $£ 6.52$ for three packs.

(i) How many packs (without splitting packs) will Mary need in order to take the HRT for a full year?

(ii) If Mary takes this treatment for a full year, how much oestrogen will she have received during this period (expressed as $\mathrm{mg}$ )?

(iii) How much medroxyprogesterone will Mary have received in a year?

(iv) What is the daily cost of this treatment (rounded up or down to nearest pence)?

\section{Answers}

\section{Question 1}

Number of staff in organisation $(100 \%)=400$

Number of women $(65 \%)=400 \div 100 \times 65=260$

Number of women who will experience symptoms $(80 \%)=260 \div 100 \times 80=208$

Number of women who will experience distressing symptoms ( $40 \%$ of those with symptoms) $=208 \div 100 \times 45=94$

Answer: 94 (rounded up).

\section{Question 2}

(i) Incidence 15/ 1000. Population of 5000: $15 \times 5=75$

(ii) Additional cases 50-59 $=2 / 1000$, Additional cases 60-69 $=2 / 1000$. Total additional cases $=4 / 1000$. In a population of $20,000=4 \times 20=80$ additional cases .

(iii) Incidence in women not using HRT = 9 women

Additional cases in women using combined HRT $=3$

$9 \div 3=3$

The incidence is a $3^{\text {rd }}$ higher

(iv) Non HRT = 10 women per 1000

Combined HRT $=6$ additional women per 1000

$60 \%$ more women

Question 3

(i) 1 year $=365$ days. 1 pack $=28$ tablets. Dose $=1$ tablet per day.

Dilyse Nuttall 
$365 \div 28=13.04$

Will need 14 packs

(ii) $365 \times 300=109500$ micrograms

Expressed as $\mathrm{mg}=109.5 \mathrm{mg}$

(iii) 1 tablet contains $1.5 \mathrm{mg} .365 \times 1.5=547.5 \mathrm{mg}$

(iv) 3 packs (total 84 tablets) $=£ 6.52$ or $652 p$

$652 \div 84=7.76 p$

Rounded up $=8 p$

\section{References}

Joint Formulary Committee (2014) British National Formulary 68 (Sept 2014), London: BMA \& RPSGB

National Institute of Health and Care Excellence [NICE] (2013) Menopause, Clinical Knowledge Summaries, available at: http://cks.nice.org.uk/menopause 